Discussion Papers in

Economics and Econometrics

2000

This paper is available on our website http://www/soton.ac.uk/ econweb/dp/dp00.html 


\title{
ENVIRONMENTAL LIABILITY AND THE CAPITAL STRUCTURE OF FIRMS
}

\author{
ALISTAIR ULPH \\ and \\ LAURA VALENTINI \\ (University of Southampton)
}

December 1999

The research for this paper was undertaken as part of a project on The Financial Implications of Environmental Legislation funded by the ESRC (L320253226), for which support we are very grateful. We are grateful to our collaborators on this project - especially Tim Jewell and George McKenzie - for useful discussions, which contributed to our thinking on this paper. An earlier version was presented at a seminar at CSERGE, UCL, and we are grateful to participants for comments. The paper was presented at the Tenth annual conference of the European Association of Environmental and Resource Economists, Crete, June 30- July 2, 2000. We are grateful to participants at the conference for useful comments. The usual disclaimer applies. 


\begin{abstract}
A number of countries have recently introduced legislation which holds polluters liable for the costs of cleaning up environmental damage they have caused. While in principle this can give polluters appropriate incentives to reduce the risk of environmental damage, these incentives are weakened if polluters enjoy limited liability and can avoid paying large damages through bankruptcy (the "judgement proofness' problem). This has led to suggestions that liability be extended to lenders such as banks, who will have incentives to condition loans on the effort made by firms to reduce environmental damage. However, this in turn can be confounded by problems of asymmetric information, and the costs imposed on banks in monitoring the environmental risks being incurred by firms. This in turn leads to fears that holding banks liable for environmental risks could substantially reduce the use of bank debt by firms.
\end{abstract}

In this paper we analyse the impact of different environmental liability regimes on the capital structure of firms, and in particular with how much bank debt they will use. We use a simple theoretical model to show that introducing environmental liability only on firms who have limited liability will cause them to increase their use of bank debt (essentially to protect their shareholders); extending liability also to banks has an ambiguous effect on bank borrowing, but under plausible assumptions will lead to lower bank borrowing than with liability only on firms, but higher or lower bank borrowing than with no liability at all.

The US has had the longest history of environmental liability legislation (CERCLA, 1980), and there have been differences over time in the extent to which banks have been held to be liable for environmental damages of insolvent firms. We use US industry-level data to estimate a reduced-form model of bank borrowing by polluters and show that the empirical model supports the theoretical findings. For industries which are heavily exposed to environmental liabilities, such as chemicals, we show that the introduction of environmental liability only on firms caused bank borrowing to increase by 15 - 20\%, but when liability was extended to banks, borrowings returned to a level only slightly higher than with no liability. Our findings suggest that extending environmental liability to banks does not have drastic consequences for bank lending to firms. 


\section{Introduction.}

Environmental policy has traditionally relied on ex ante regulation (emission standards, technology standards, economic instruments) to induce polluters to reduce their emissions. But recently some countries have moved towards ex post regulation: whereby polluters are made strictly liable for the costs of the environmental damage they have already caused. In principle, the anticipation of these liabilities will provide polluters with appropriate incentives to reduce the risk of environmental damage (this can be thought of as an application of the Coase Theorem). However, this incentive to reduce pollution is weakened if polluters enjoy limited financial liability and can avoid paying large damages by becoming insolvent (they become 'judgement proof').

One possible solution to this problem that has been proposed is to extend environmental liability also to lenders such as banks. Provided they too are not liable to bankruptcy (they have 'deep pockets') they will have incentives to condition their loans on the efforts firms make to reduce the risk of environmental liabilities, and, again in principle this will ensure that efficient levels of pollution abatement are undertaken (Segerson (1993)). However, this solution is in turn problematic if there are significant asymmetries of information between banks and firms so that it is either impossible or expensive for banks to properly monitor environmental risks being run by firms. If there are significant problems of asymmetric information then this may result in both inefficiently low levels of environmental care being taken by polluters and also distortions to the capital structure of firms. If only firms are held liable for environmental damages, and they have limited liability, then firms may take on too much bank debt to protect shareholders against environmental risks. On the other hand if banks are also held liable, then firms may take on too little bank debt if either banks impose significant charges to cover monitoring costs or banks use credit rationing in response to the asymmetry of information.

The best known use of environmental liability legislation is in the USA which introduced the Comprehensive Environmental Response Compensation and Liability Act (CERCLA) in 1980. This Act holds 'potentially responsible parties' (PRP's) jointly and severally liable to pay for the clean-up of contaminated properties. PRP's are owners and operators of sites. The Act contained a 'Secured Creditor Exemption' whereby lenders were exempt from liability as long as the property was kept mainly as security for a loan. There were a number of tests of this exemption, and in 1992 the EPA issued a ruling which said that lenders could only be liable as owners if they foreclosed on a loan (which meant that lenders avoided foreclosure) or as operators of they were "involved in the day-to-day management of the insolvent firm". There were a few cases where this was invoked - e.g. where an employee of a bank was on the board of directors. But the case which seemed to open up banks more widely to liability was the Fleet Factors case (1990) where the judge ruled that banks could be

\footnotetext{
${ }^{1}$ On the other hand, an argument sometimes advanced for imposing environmental liability on banks is that if banks are already monitoring conventional credit risks, then there may be economies of scope in extending this monitoring role to include environmental risks, and this could reduce the costs of monitoring using traditional ex ante regulation.

${ }^{2}$ See Pitchford (1995), Boyer and Laffont (1997), Balkenborg (1997) Lewis and Sappington (1997).
} 
held to have a "capacity to influence" the environmental risks run by operators. The argument was that lenders could not gain exemption from liability by pleading ignorance, since this would reduce the incentives for banks to carry out environmental audits as part of the normal prudential credit approval process. This seemed to imply that the normal monitoring of credit risks by banks would have to include environmental risks and hence give banks a knowledge of and therefore capacity to influence the steps taken by firms to affect environmental risks. Thus for a period of time in the US there was a view that banks as well as firms could be held liable for environmental damages.

In the UK the Environment Act (1995) introduced strict liability on PRP's for cleaning up contaminated land. The draft guidance notes for implementation of the Act applies six sequential exemption tests which appear to ensure that banks are exempt from liability (see Jewell (1997 a, b) for a legal analysis of the EA). However, these have still to be tested in court, and there is evidence that UK banks still believe there is a small risk they could be held liable for environmental damages of insolvent borrowers (McKenzie and Wolfe (1998)). Elsewhere in Europe there are variations in liability regimes, and while in principle lenders could be held liable on the same two grounds as in the US, no lender has yet been held liable. The EU has been considering proposals for harmonisation of liability regimes.

In this paper we are concerned primarily with an empirical analysis of how the environmental liability regimes in the US have affected the capital structure of firms, and in particular the extent to which firms have relied on long-term bank borrowing. In section 2 we shall set out a simple theoretical model of firms' choice of capital structure and show how different environmental liability regimes affect bank borrowing. We shall show that if only firms are held liable, and they have limited financial liability, then firms will take on an inefficiently high level of bank debt, essentially to protect their shareholders from environmental liabilities. If firms and banks are held jointly liable, then we show that the effect on bank borrowing is ambiguous. However, on plausible assumptions the level of bank borrowing will be lower with joint liability than with liability only on firms; bank borrowing may be higher or lower with joint liability than when there is no liability.

In section 3 we use US industry-level data to estimate a reduced-form model of longterm bank debt over three time phases: (i) pre-1980 (i.e. pre-CERCLA): no liability; (ii) 1981-1990 (post-CERCLA, pre-Fleet Factors): liability only on firms; (iii) post1991 (i.e. post-Fleet Factors) joint liability on firms and banks. We show that the empirical analysis strongly supports the theoretical predictions: bank borrowing rises when liability is imposed only on firms; when liability is extended to banks, then bank borrowing is lower than when liability is imposed only on firms, but is slightly higher than with no liability at all. For industries, such as Chemicals, which are heavily exposed to CERCLA liabilities, the model predicts that imposing environmental liabilities on firms would cause bank borrowing to rise by $15-20 \%$, ceteris paribus, while if liability is imposed jointly on firms and banks then bank borrowing in such heavily exposed industries would only be about 1-2\% above the level without any liability. Our results do not suggest that extending environmental liabilities to banks, which would be desirable in terms of improving the level of effort 
firms make to reduce environmental risks, would have a drastic effect on bank borrowing by firms. 


\section{The Theoretical Model}

In this section we set out a simple theoretical model to show how different liability regimes affect the choice of capital structure by firms. The model extends the work of Feess and Hege (1997), which, to our knowledge, is the first paper which focuses explicitly on the impact of liability regimes on capital structure.

We analyse a firm which is deciding whether to undertake a project with investment cost $I$, and if so, how to finance it. There are three possible ways of funding the project: by equity, supplied by the owner-manager (hereafter owner) of the firm who has initial wealth $W$; or by debt which can take the form of either bank (private) debt or by public debt (corporate bonds). Both forms of debt are supplied on competitive markets ${ }^{2}$, and we denote by $D$ the amount of debt used. The two forms of debt are equivalent except for a lump sum benefit or cost of using bank debt rather than public debt, denoted by $m$ which may reflect factors such as better monitoring or negotiation capacity of the bank or the higher cost of bank debt. Thus $m$ may be positive (if the benefit of bank debt outweighs the cost) or negative (the reverse occurs). The fixed cost nature of this benefit/cost means that the firm will only choose one form of debt. Denote by $\Phi$ a variable which takes the value 1 if the firm chooses bank debt and the value 0 if it chooses public debt. Then $Z(\Phi, m) \equiv(2 \Phi-1) m$ is the gain (or loss) to the owner from the choice of public or private debt. Finally $I-D$ is the amount of funds supplied by the owner to finance the project. The owner is assumed to be risk neutral.

Rather than explicitly model why the capital structure might matter to the firm, we simply assume that the return to the project, $R(D)$, is a strictly concave function of $D$, where $D^{*}=\operatorname{argmax}(R(D)), \quad 0<D^{*}<I$, is the optimal level of debt. This formulation is consistent with a wide range of theories of optimal capital structure, such as tax shields, signalling, costs of financial distress. Finally we assume that $I-D^{*}$ $<W<I$ so that the owner can finance the equity required for the optimal capital structure, but not the whole project. Indeed we shall make the stronger assumption that for all relevant values of $D, W>I-D$; this assumption is made just to avoid having to worry about cases where the owner is wealth constrained.

We assume that the project carries a risk of causing environmental damage $X$, with probability $P(e)$, where $e \geq 0$ is the level of care expenditure made by the firm. For all $e \geq 0,1 \geq P(e) \geq 0$ and $P^{\prime}(e)<0, P^{\prime \prime}(e)>0$. We suppose that the firm chooses $e$ at the start of the project and that it is possible to condition debt or insurance contracts on $e$ (though, as noted below, there may be costs to monitoring such effort).

We denote by $L \leq X$ the level of liability imposed by a regulator. The aim of the regulator is to maximise welfare, which is defined as profits earned by the owner minus expected environmental damage net of any liability payments. We shall consider in turn five possible regimes for how liability may be imposed: Regime 0 : No liability; Regime I: Liability only on the firm with compulsory insurance with costless monitoring; Regime II: Liability only on the firm with compulsory insurance

\footnotetext{
${ }^{3}$ The assumption of competitive markets is significant. Heyes (1996) and Balkenborg (1997) show that the conclusions drawn by Pitchford (1995) about the implications of environmental liability in models of competitive banking with asymmetric information do not all carry through when the banking market is imperfectly competitive.
} 
with costly monitoring; Regime III: Liability only on the firm with no requirement for insurance; Regime IV: Liability jointly on the firm and any bank which has lent to the firm, but no requirement for insurance.

\subsection{Regime 0: No Liability}

In this regime the firm is not held liable for any damages in the event of any environmental accident occurring, so clearly it will make no investment in care expenditure, i.e. $e=0$. The owner has then to choose the capital structure (i.e. how much of the investment cost $I$ is financed with debt $D$ or with equity) and the form of debt, bank or public, $\Phi . D$ and $\Phi$ are chosen to maximise:

$$
\Pi(D, \Phi)=[R(D)-D]-[I-D]+(2 \Phi-1) m
$$

where the first term is the value of the equity-holding of the owner, the second term is the equity invested by the owner, and the third term is the net gain/cost from the choice of private or public debt. We can rearrange (1) as:

$$
\Pi(D, \Phi)=R(D)-I+(2 \Phi-1) m
$$

Given the separable nature of $\Pi$, the choice of $D$ and $\Phi$ can be simply summarised by:

i) choice of $D: D$ is chosen so to maximise $\Pi(D, \Phi)$ or equivalently $R(D)$ so $D=D^{*}$;

ii) choice of $\Phi: \quad \Phi=1$ if $m \geq 0$ and $\Phi=0$ if $m<0$. Call this assignment rule $\Phi^{*}$. Then $Z\left(\Phi^{*}, m\right)=|m|$.

Thus without liability the firm earns profits: $\Pi_{0} \equiv R\left(D^{*}\right)-I+|m|$ and society gets welfare $V_{0} \equiv \Pi_{0}-P(0) X$.

\subsection{Regime I: Liability on Firm with Compulsory Insurance with Costless Monitoring}

We assume that a regulator imposes a liability $L$ on the firm, and requires that the firm can pay this liability through appropriate insurance. Before allowing the project to proceed the regulator requires that the firm demonstrates how its liability is to be insured. This can take the form of self-insurance, denoted by $S$, where the owner pledges to cover the amount $S$ of the liability; the balance $L-S$ must then be insured externally, and we assume that there is a competitive market in insurance contracts, offered by either insurance companies or banks. For this section we assume that both banks and insurance companies can costlessly monitor the level of care expenditure, $e$, undertaken by the firm, and hence can costlessly observe $P(e)$, the probability of environmental liability being incurred. The level of self-insurance, $S$, is subject to an upper bound by the available wealth of the owner, defined as:

$$
\bar{S}(D) \equiv W-(I-D)+(R(D)-D=W+R(D)-I
$$


There are three components of the owner's maximum available wealth: initial wealth $W$, less the costs of the funds put up to fund the project $(I-D)$, plus the equity returns on the project $(R(D)-D)$.

With our assumption of costless monitoring and competitive insurance markets, the cost to the owner of external insurance is just the actuarial premium $P(e)(L-S)$, while the cost of self-insurance is simply $P(e) S$.

The problem facing the owner can now be summarised as choosing the capital structure of the firm, $D$, the form of debt, $\Phi$, the level of care expenditure, $e$, and the level of self insurance, $S$, to maximise:

$$
\begin{gathered}
\Pi(D, \Phi, e, S \mid L) \equiv[R(D)-D]-[I-D]-[P(e) S+P(e)(L-S)+e]+(2 \Phi-1) m \\
=R(D)-I-[P(e) S+P(e)(L-S)+e]+(2 \Phi-1) m \\
\text { s.t. } \quad S \leq \bar{S}(D)
\end{gathered}
$$

It is clear from the formulation of (4) that the solution decomposes into three stages:

(i) Choice of $e$ and $S$ : the owner-manager chooses $e$ and $S$ to minimise:

$$
\begin{aligned}
& p(e) S=p(e)(L-S)+e=p(e) L+e \\
& \text { s.t. } S \leq \bar{S}(D)
\end{aligned}
$$

The objective function does not depend on $\mathrm{S}$ since the owner is completely indifferent between self-insurance and external insurance. For simplicity we assume $S=0$. e is then chosen to minimise $p(e) L+e$. Denote the solution by $E(L)$, where $E(L)$ satisfies the first order condition:

$$
p^{\prime}[E(L)] L+1=0
$$

This is just the usual condition that the marginal cost of effort equals the marginal reduction in the expected cost of liability. Totally differentiating (5) yields:

$$
E^{\prime}(L)=-\frac{p^{\prime}}{p^{\prime \prime} L}>0
$$

so that the optimal level of care is an increasing function of liability.

Finally denote by $K(L)=p(E(L)) L+E(L)$ the minimum cost to the owner of facing liability $L$ under costless mandatory insurance. Note that $K^{\prime}(L)=p(E(L))>0$.

(ii) Choice of $D$. While the level of $D$ affects the upper bound of self-insurance, we have seen that this plays no role, so $D$ is chosen simply to maximise $R(D)$, i.e. $D=$ $D^{*}$, the same as with no liability.

(iii) Choice of $\Phi$. As with no liability the owner will choose $\Phi$ by the rule $\Phi *$ i.e. $\Phi=$ 1 if $m \geq 0, \Phi=0$ if $m<0$. 
Thus for any given level of liability $L$ with mandatory costless insurance the firm chooses $D=D^{*}, e=e^{*}=E(L), S=0, \Phi=\Phi^{*}$ and earns profits

$$
\Pi^{*}(L) \equiv R\left(D^{*}\right)-I-K(L)+|m|
$$

We now consider the problem of the regulator in setting $L$. This is chosen to maximise social welfare, defined as profits less the expected costs of damage not covered by liability payments, i.e. $L$ is chosen to maximise:

$$
\begin{aligned}
& V(L) \equiv \Pi^{*}(L)-p(E(L))[X-L] \text { for which the first order condition is: } \\
& \frac{d \Pi *(L)}{d L}-p^{\prime} E^{\prime}[X-L]+p[E(L)]=0
\end{aligned}
$$

Since $\frac{d \Pi^{*}(L)}{d L}=-K^{\prime}(L)=-p[E(L)]$ (7) reduces to

$-p^{\prime} E\{X-L]=0 \quad$ i.e. $\quad L=L^{*}=X$

This is just the obvious condition that with costless mandatory insurance it is optimal to impose full liability on the firm.

Thus with costless mandatory insurance we get the first-best outcome:

(i) the externality is fully internalised as a liability to the firm $\left(L=L^{*}=X\right)$;

(ii) the firm chooses effort so that $p^{\prime}(e) X+1=0$, i.e. the marginal cost of a bit more effort equals the marginal benefit of reduced expected environmental damage cost;

(iii) the firm makes the optimal choice of capital structure, $D=D^{*}$;

(iv) the firm makes the optimal choice of private or public debt, $\Phi=\Phi^{*}$

This is the first-best solution that would be obtained if the regulator had directly chosen $D, e, \Phi$ to maximise

$$
R(D)-I-e-p(e) X+(2 \Phi-1) m
$$

i.e. profits minimise expected environmental damage costs. Instead, the regulator only has to set liability $L=L^{*}=X$ and leave it to the profit-maximising owner to choose the first-best values for $D, e$ and $\Phi$.

Finally note that the project should only proceed if $V\left(L^{*}\right) \geq 0$, i.e. $\Pi^{*}(X) \geq 0$.

\subsection{Regime II: Liability on Firm with Compulsory Insurance with Costly Monitoring}

As in the previous section we assume that the regulator imposes as a liability $L$ on the owner in the event of environmental damage being incurred and requires that this risk is fully insured, either by self insurance or through external insurance contracts. But now we suppose that there is a moral hazard problem: banks and insurance companies 
cannot costlessly monitor $e$. If the owner has announced care expenditure $E(L)$, of which an amount $S, O \leq S \leq L$ is self-insured, and $E(L)$ cannot be observed, the firm would have an incentive to carry out only expenditure level $E(S) \leq E(L)$. If the owner manager wants to commit to a level of effort $e>E(S)$, then banks and insurance companies will have to carry out monitoring activities which are costly円

We assume that banks and insurance companies incur monitoring costs

$$
C(e, S) \equiv \gamma[e-E(S)] \quad e \geq E(S)
$$

where $\gamma$ is an increasing strictly concave function $\left(\gamma^{\prime} \geq 0, \gamma^{\prime}>0\right)$ with $\gamma(0)=\gamma^{\prime}(0)=0$, i.e. the marginal cost of doing the first bit of monitoring is zero. While the cost function $C(e, S)$ is common to both bank and insurance companies, we also assume that there is a fixed cost difference between banks and insurance companies in monitoring costs denoted by $\delta$, where $\delta>(<) 0$ means that banks incur higher (lower) monitoring costs than insurance companies. Thus the cost of monitoring by a bank is: $\gamma(e-E(S))+\delta$. Finally we assume that if a firm decides to borrow from a bank, then it has a choice of whether to insure from a bank or from an insurance company; while if the firm uses public debt, then it must use insurance companies to monitor its activities. This assumption is meant to capture the possibility that there may be economies of scope in a bank monitoring both the financial and environmental risks of a loan and the bank is only willing to incur the costs of monitoring the insurance risk if it is also monitoring the loan. Thus there is an additional benefit from using bank debt, that the firm maybe able to reduce monitoring costs by an amount $b=$ $\min (0, \delta)$.

We continue to assume that the market for insurance by either banks or insurance companies is competitive, so that the firm has to pay the full cost of both the actuarially fair insurance premium and the cost of monitoring for any liability that is not self-insured. The problem for the owner faced with liability $L$ and mandatory costly insurance is to choose $D, \Phi, e, S$ to maximise:

$$
\begin{gathered}
\hat{\Pi}(D, \Phi, e, S \mid L) \equiv R(D)-I-[p(e) L+e+\gamma[e-E(S)]+(2 \Phi-1)-\Phi b \\
\text { s.t. } \quad S \leq \bar{S}(D)
\end{gathered}
$$

(8) differs from (4) by the inclusion of the cost of monitoring. Again it is possible to decompose the decision into three stages.

(i) Choice of $e$ and $S$. For any given $D$, and hence $\bar{S}(D)=W-I+R(D)$, the firm chooses $e$ and $S$ to minimise:

$$
p(e) L+e+\gamma[e-E(S)] \quad \text { s.t. } S \leq \bar{S}(D)
$$

\footnotetext{
${ }^{4}$ Note that the assumption that $e$ can be monitored, albeit at a cost, and therefore debt and insurance contracts can be conditioned on $e$, is an important one. Pitchford (1995), Balkenborg(1997), Heyes (1996), Boyer and Laffont (1997) analyse the case when there is a moral hazard problem but without the possibility of monitoring $e$, so any debt or insurance contract can condition payments only on whether or not an environmental accident occurs.
} 
It is obvious that to minimise these costs, the firm should choose the maximum level of self-insurance, since this minimises monitoring costs. This leaves the problem of choosing $e$ to minimise: $p(e) L+e+\gamma[e-E(\bar{S}(D))]$ for which the first order condition is:

$$
p^{\prime} L+1+\gamma^{\prime}=0
$$

Define the solution as $\hat{E}(L, D)$. Total differentiation of (9) shows that:

$$
\frac{\partial \hat{E}}{\partial L}=\frac{-p^{\prime}}{\left[p^{\prime \prime} L+\gamma^{\prime \prime}\right]}>0, \quad \frac{\partial \hat{E}}{\partial D}=\frac{\gamma^{\prime \prime} E^{\prime} R^{\prime}}{\left[p^{\prime \prime} L+\gamma^{\prime \prime}\right]}
$$

So effort will be an increasing function of liability ${ }^{\square}$, but the effect of an increase in debt on care expenditure depends on the sign of $R^{\prime}:$ if increasing debt increases $R$, and hence the maximum amount of self insurance, then care expenditure will increase. Note also that as long as $L>\bar{S}(D)$ then $\hat{E}(L, D)<E(L)$, i.e. the optimal effort level with costly insurance is less than with costless insurance, for the simple reason that the firm has to pay the monitoring costs of committing to higher levels of effort.

Define $\hat{K}(L, D) \equiv p[\hat{E}(L, D)] L+\hat{E}(L, D)+\gamma[\hat{E}(L, D)-E(\bar{S}(D)]$ as the minimum cost of insuring against liability $L$ when the debt level of the firm is $D$. It is straightforward to see that:

$$
\frac{\partial \hat{K}}{\partial D}=-\gamma^{\prime} E^{\prime} R^{\prime}, \quad \frac{\partial \hat{K}}{\partial L}=p[\hat{E}(L, D)]
$$

(ii) Choice of $D$. We can now solve the problem of the firm as choosing $D$ and $\Phi$ to maximise:

$$
R(D)-I-\hat{K}(L, D)+(2 \Phi-1) m-\Phi b
$$

The first order condition is:

$$
R^{\prime}(D)-\frac{\partial \hat{K}}{\partial D}=R^{\prime}(D)+\gamma^{\prime} E^{\prime} R^{\prime}(D)=0 \Rightarrow R^{\prime}(D)=0 \Rightarrow D=D^{*}
$$

Thus, since the firm wishes to maximise self insurance, and the limit on self insurance is increasing in the returns on the project, this simply reinforces the firm's wish to choose the capital structure which maximises the returns to the project. Because of mandatory insurance cover, there is no incentive to increase debt as a means of passing liability on to lenders. This would still need to be covered by mandatory insurance and increasing debt beyond $D^{*}$ just reduces the scope for selfinsurance and so increases the monitoring cost the firm has to pay.

\footnotetext{
${ }^{5}$ Note that this result depends crucially on the assumption that effort can be monitored. As noted in footnote 1 , in other models where effort cannot be monitored, payments can depend only on whether or not an environmental accident has occurred, and, as shown by Pitchford (1995), in such models increasing liability may reduce the care effort made by firms.
} 
(iii): Choice of $\Phi$. If the firm chooses to use bank debt then it gets a net benefit of $m-b$ where $b=\min \{0, \delta\} \leq 0$; if it chooses to use public debt then it receives a net benefit of $-m$. So the firm will choose bank debt $(\Phi=1)$ if $m \geq b / 2$, and public debt $(\Phi=0)$ if $m<b / 2$. Call this assignment rule $\hat{\Phi}$. Since $b \leq 0$, then in general there will be a wider range of values of $m$ for which bank debt will be chosen compared to the case of costless monitoring, because the choice of bank debt now offers a choice of monitoring agency which is not available if public debt is chosen. Using this rule the value of the net benefit of choosing the optimal type of debt is $\left|m-\frac{b}{2}\right|$.

To summarise, for any given liability level, $L$, with mandatory but costly insurance the firm chooses $D=D^{*}, e=\hat{E}\left(L, D^{*}\right), S=\bar{S}\left(D^{*}\right), \Phi=\hat{\Phi}$, and earns profits:

$$
\hat{\Pi}(L) \equiv R\left(D^{*}\right)-I-\hat{K}\left(L, D^{*}\right)+\left|m-\frac{b}{2}\right|
$$

The regulator will choose $L$ to maximise $\hat{V}(L)=\hat{\Pi}(L)-p\left(\hat{E}\left(L, D^{*}\right)\right)(X-L)$ for which the first order condition is:

$$
\frac{\partial \hat{\Pi}}{\partial L}-p^{\prime} \frac{\partial \hat{E}}{\partial L}(X-L)+p\left(\hat{E}\left(L, D^{*}\right)\right)=0
$$

Since $\frac{\partial \hat{\Pi}}{\partial L}=-\frac{\partial \hat{K}}{\partial L}=-p\left[\hat{E}\left(L, D^{*}\right)\right]$ (10) again gives the optimal rule for liability: $L=\hat{L}=X$. This is the optimal second best outcome in which with mandatory coverage and costly monitoring: there is full internalisation of environmental damage costs, the firm chooses the first best capital structure, as in the first-best with mandatory insurance and costless monitoring; but there is a lower level of care expenditure, $\hat{E}\left(X, D^{*}\right)<E(X)$, and there will be a wider range of values $m$ for which bank debt is preferred to public debt, compared to the case of costless monitoring. Again this outcome is exactly the same as if the regulator chose all the variables $e, S, D$ and $\Phi$; so the second-best outcome can be achieved by just imposing mandatory insurance cover with full liability for environmental damage, and leave it to the firm to choose the second-best level of care expenditure and financial structure.

\subsection{Regime III: Liability of the Firm with No Mandatory Insurance}

We now assume that in the event of environmental damage being incurred the firm is required to pay liability $L$, but is no longer required to insure this liability, either by itself (self-insurance) or by external parties. We continue to assume that an external insurance contract will involve paying costly monitoring services to overcome the moral hazard problem. Because of limited liability, the maximum amount for which the owner may be held directly liable is just the equity invested in the firm:

$$
R(D)-D \leq \bar{S}(D)=W+R(D)-I
$$


(since $I-D \leq W)$. Since there is no requirement to take out insurance to cover any liability greater than $R(D)-D$, it is clear that the firm can simply ignore any liability greater than $R(D)$ - $D$ and, since monitoring by external agencies is costly, has no incentive to take out any external insurance. Define $\Psi(L, D)=\min (L, R(D)-D)$. Then, $S=\Psi(L, D)$, and the problem for the firm is to choose $D, e$ and $\Phi$ to maximise:

$$
\Pi(D, e, \Phi \mid L) \equiv R(D)-I-[p(e) \Psi(L, D)+e]+(2 \Phi-1) m
$$

Again the solution can be decomposed as follows:

(i) Choice of $e$. Since (11) is similar to (4), it is clear that the optimal choice of $e$ is given by $e=\tilde{E}(L, D)=E(\Psi(L, D))$. If $L<R(D)-D$, $\frac{\partial \tilde{E}}{\partial L}=E^{\prime}>0 ; \frac{\partial \tilde{E}}{\partial D}=0$. While if $L \geq R(D)-D \frac{\partial \tilde{E}}{\partial L}=0, \quad \frac{\partial \tilde{E}}{\partial D}=E^{\prime}\left(R^{\prime}-1\right)$ which says that the effect of an increase in debt on care expenditure depends on the sign of $R^{\prime}$ - 1, i.e. if an increase in debt increases the equity value of the firm (because it increases returns more than it increases debt) than this will increase care, because more of the owner's equity is at risk. However if increasing debt reduces the equity value of the firm then that will reduce the care taken by the firm.

It is straightforward to see that $\tilde{E}(L, D) \leq \hat{E}(L, D)<E(L)$, where the first inequality arises because $\tilde{E}(L, D)=E(\Psi(L, D)) \leq E(\bar{S}(D)) \leq \hat{E}(L, D)$.

Finally define $\tilde{K}(L, D)=p[\tilde{E}(L, D)] \Psi(L, D)+\tilde{E}(L, D)$ as the minimum cost of facing environmental liability $L$ when the firm has debt $D$ and limited liability. If $L<R(D)$ $D, \frac{\partial \tilde{K}}{\partial L}=p(\tilde{E}), \frac{\partial \tilde{K}}{\partial D}=0$, while if $L \geq R(D)-D \frac{\partial \tilde{K}}{\partial L}=0, \frac{\partial \tilde{K}}{\partial D}=p(\tilde{E})\left[R^{\prime}-1\right]$. In the rest of this section we shall concentrate on the more interesting case where $L \geq R(D)-D$.

(ii) Choice of $D$. The firm chooses $D$ to maximise: $R(D)-I-\tilde{K}(L, D)+(2 \Phi-1) m$

for which the first order condition is: $R^{\prime}(D)-\frac{\partial \tilde{K}}{\partial D}=0 \Rightarrow R^{\prime}(D)=-\frac{p}{(1-p)}<0$. So the optimal level of debt is $D=\tilde{D}>D^{*}$. Thus if the liability is imposed only on the firm, with no requirement for mandatory insurance cover, and the firm can limit its liability to the equity holding, then there is a clear incentive to distort the capital structure in the direction of too much debt.

(iii) Choice of $\Phi$. As in the first-best case, the firm will choose $\Phi=\Phi^{*}$, i.e. use bank debt if $m>0$ and public debt if $m<0$.

In summary, assuming that $L \geq R(\tilde{D})-\tilde{D}$, the firm sets $e=\tilde{E}(L, \tilde{D}), \quad D=\tilde{D}, \Phi=\Phi$ * and earns profits: $\tilde{\Pi}(L) \equiv R(\tilde{D})-I-\tilde{K}(L, \tilde{D})+|m|$ 
Since (12) does not depend on $L, \tilde{\Pi}^{\prime}(L)=0$.

For $L \geq R(\tilde{D})-\tilde{D}$, social welfare is $\tilde{V}(L) \equiv \tilde{\Pi}(L)-p[\tilde{E}(L, \tilde{D})][X-(R(\tilde{D})-\tilde{D})]$. Thus any liability in the range $R(\tilde{D})-\tilde{D} \leq L \leq X$ will lead to exactly the same outcome, and so the best the regulator can do is to achieve care level $\widetilde{E}(L, \tilde{D})$. So if the only instrument available to the regulator is the level of liability, and if the regulator cannot impose mandatory insurance cover, then the level of care expenditure will be below the second best level, while the capital structure of the firm will be distorted to give too high a level of borrowing. The choice of bank or public debt is the same as the simple rule $\Phi^{*}$ which the firm followed with either no liability or in the first best case with liability and mandatory insurance with costless monitoring.

\subsection{Regime IV: Joint Liability on Firm and Bank, no mandatory insurance}

Finally we analyse the case where liability $L$ is imposed jointly on the firm and bank lender, so that in the event that the liability cannot be paid by the owner, then it will be paid by the bank, if the firm has borrowed from a bank. Note that if the firm has used public debt, then it is assumed that it is not possible for individual holders of corporate debt to undertake any monitoring of the firm's behaviour, and so they would be exempt from any liability.

We follow Feess and Hege(1997) in noting that this case can be viewed as a combination of the two previous cases. If the firm decides to borrow from a bank, then the bank will insist that any liability to which it is exposed must be fully covered by insurance and the level of care expenditure appropriately monitored. The outcome will thus be as if we were in the regime of mandatory insurance with costly monitoring, except that the firm has chosen to use bank financing, i.e. $\Phi=1$. The solution, as in Regime II, will result in the firm setting $D=D^{*}$, $S=\bar{S}\left(D^{*}\right), e=\hat{E}\left(L, D^{*}\right)$ and will yield the firm profits:

$$
\bar{\Pi}^{1}(L) \equiv R\left(D^{*}\right)-I-\hat{K}\left(L, D^{*}\right)+m-b
$$

(13) differs from (10) only in the last term because $\Phi=1$, necessarily, rather than being set optimally.

On the other hand if the firm chooses public debt, then holders of public debt cannot be held liable, and then, as in Regime III, the owner can only be held liable to the extent of the equity invested in the firm. So if $\Phi=0$ the firm will set $D=\tilde{D}, S=R(\tilde{D})-\tilde{D}, e=\tilde{E}(L, \tilde{D})$ and earn profits:

$$
\bar{\Pi}^{0}(L) \equiv R(\tilde{D})-I-\tilde{K}(L, \tilde{D})-m
$$

which again differs from (12) because $\Phi$ is necessarily 0 rather than being chosen optimally. 
The only decision left now is for the firm to choose which form of debt it will use, and it will choose bank debt $(\Phi=1)$ iff:

$$
\begin{aligned}
& R\left(D^{*}\right)-I-\hat{K}\left(L, D^{*}\right)+m-b \geq R(\tilde{D})-I-\tilde{K}(L, \tilde{D})-m \\
& \text { i.e.iff } m \geq \frac{b+\theta}{2} \text { where } \theta \equiv[R(\tilde{D})-K(L, \tilde{D})]-\left[R\left(D^{*}\right)-K\left(L, D^{*}\right)\right]
\end{aligned}
$$

Now it is straightforward to see that $\theta \geq 0$, since the second term in brackets is the result of choosing $e$ and $D$ to maximise:

$$
G^{1}(e, D) \equiv R(D)-[p(e) L+\gamma(e-E(\bar{S}(D)))+e]
$$

while the first term in brackets is the result of choosing $e$ and $D$ to maximise:

$$
G^{0}(e, D) \equiv R(D)-[p(e)(\min \{L,(R(D)-D)\})+e]
$$

$\theta \geq 0$ because $G^{0}(e, D) \geq G^{1}(e, D), \quad$ for two reasons: the limitation of potential liability the firm is exposed to, and the fact that there is no need to pay monitoring costs.

Now in the case of no liability (Regime 0 ), liability with mandatory insurance and costless monitoring (Regime I) and liability of the firm with no mandatory insurance (Regime III), the firm will choose bank debt iff $m \geq 0$; in the case of liability and mandatory insurance with costly monitoring (Regime II) the firm will choose bank debt iff $m \geq b / 2$; so (16) tells us that with joint liability on the firm and the bank (Regime IV) the firm will use bank debt for a lower range of parameter values than Regime II, and will use it less (more) than in Regimes $0, I$ and $I I I$ if $\theta \geq-b / 2(\theta<$ $b / 2)$; recall that $b=\min (0, \delta)$ is non-positive.

Thus if lender liability is imposed on the firm and bank jointly, then, if the firm chooses bank debt we will get the second best level of care expenditure and the firstbest capital structure, but if it chooses public debt, we will get inefficiently high level of debt and less than second-best level of care expenditure. The firm is more likely to choose public debt than in the second-best assignment rule.

\section{$\underline{\text { 2.6 Summary }}$}

This completes the analysis of the outcomes of the five liability regimes. We now summarise the implications of these results for the empirical analysis which follows. We shall model bank borrowing over three time periods: (i) pre-CERCLA, which corresponds to Regime 0: No Liability; (ii) post-CERCLA but pre-Fleet-Factors, which we shall take to correspond to Regime III: Liability only on Firm, with No Mandatory Insurance; and (iii) post-CERCLA and post-Fleet-Factors which we shall take to correspond to Regime IV: Joint Liability on Firm and Bank, with No Mandatory Insurance. We are interested in how the extent of bank borrowing by different industries varies across the three phases, or equivalently Liability Regimes, and the analysis shows that this depends on two factors: the level of debt, $D$, and whether borrowing was from banks or from the public, $\Phi$. 
The analysis shows that moving from phase (i) to phase (ii), i.e. when CERCLA introduced liability on firms only, but without mandatory insurance, should unambiguously increase bank borrowing: the firm will choose debt level $\tilde{D}>D *$ and will choose to use bank rather than public borrowing for the same parameter values as with no liability ( $\Phi=1$ iff $m \geq 0$ ). Moving from phase (ii) to phase (iii), by extending liability fully to banks, will have an ambiguous effect on bank borrowing; first, the level of borrowing will revert to the pre-liability (phase (i)) level of debt $\left(D^{*}\right)$, so bank lending would fall; but, compared to the no liability case, the firm will make more or less use of bank borrowing depending on whether $\theta<-b / 2$ or $\theta \geq-b / 2$. In general one would expect that the unambiguously negative effect of the first factor would mean that bank lending would be less when liability is extended from the firm to include the bank, but the ambiguity of the second factor means that it is not possible to predict whether bank borrowing with joint liability would be greater or less than bank borrowing with no liability. If the second effect is weak, then one would expect bank borrowing to return to close to the pre-CERCLA level. 


\section{Empirical Analysis of the Effects of Environmental Liability on Bank Borrowing.}

In this section we use US data to estimate the effect of both CERCLA and the Fleet Factors case on the level of industrial bank borrowing. We estimate a reduced-form model of bank borrowing over the period 1973-97 using data for 14 industries, and use dummies for both CERCLA and Fleet Factors to divide the period into three phases: (i) pre-CERCLA: No Liability; (ii) post-CERCLA, pre-Fleet-Factors: Liability only on Firms; (iii) post-CERCLA and post-Fleet-Factors: Joint Liability on Firms and Banks. To motivate our choice of variables for the reduced-form model of

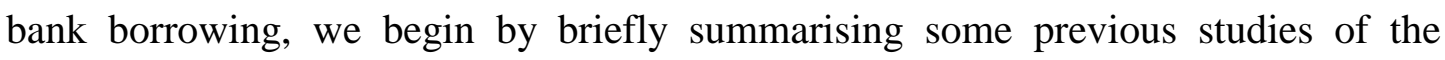
determinants of firms' capital structure.

\subsection{Survey of Previous Studies of Firms' Capital Structure.}

We focus on the relationship between firms' characteristics and firms' capital structure. The quantity of commercial loans taken out by firms is the equilibrium result of the profit-maximising behaviour of firms and banks, and in summary it is determined by three types of variables: macroeconomic variables, such as interest rates or GNP (affecting both demand and supply); supply variables, reflecting credit suppliers' characteristics and their preferences over customers' characteristics; demand variables reflecting firms' choice of capital structure. When estimating a reduced-form function to explain bank borrowing by firms these three sets of variables interact, sometimes with opposite effects on supply or demand. This may leave undetermined the net effect and thus the sign and the statistical significance of a reduced form regression.

Firms' capital structure concerns the proportion of equities over debt, the proportion of debt that is publicly issued or privately borrowed and the term structure of debt. The main decision about capital structure studied in the literature concerns the proportion of debt to borrow privately and the proportion to borrow publicly. Bank financing is considered less expensive than public debt, only larger firms thus rely on public debt, because they can spread fixed issuance costs over a larger amount. On the other hand monitoring costs from banks may make bank lending more expensive.

The demand for bank loans depends on interest rates, the costs of alternative funds and firms' characteristics. The supply of bank loans depends again on interest rates, deposits and capital requirements, banks' costs, and firms' characteristics, since banks will prefer to allocate to less risky firms than to more risky ones. We survey three studies: Johnson (1997), Houston and James (1996), Titman and Wessels (1988), which for brevity will be referred to as J, HJ and TW; these studies use reduced form regressions of the proportion of long-term private debt on firms' characteristics. Some of these characteristics are not directly observable and thus proxies or indicators are used instead. The firms' characteristics considered are the following:

Age: this is usually measured by the numbers of years since incorporation. Age is used as a proxy of reputation: older firms have developed a reputation for reliability

${ }^{6}$ See Valentini (1999) for a more extensive survey. 
and thus can rely more on public debt. On the contrary younger firms may be considered too costly to administer and monitor by the banks, and do not necessarily have to rely on bank debt. The relationship is thus that older firms have a higher proportion of public debt, while very young firms have a higher proportion of private non-bank debt. Middle aged firms should have a higher proportion of bank debt. J finds a positive coefficients of age in estimating long run public debt, while for bank debt the coefficient was not significant and for private non-bank debt it is negative.

Size: The leverage ratio may be also related to size as well as the term structure of debt. Small firms rely more heavily on bank debt than larger firms, and usually prefer short term debt rather than issuing larger term debt because of the lower fixed costs associated with this alternative. Size is usually measured by sales or total assets or quit rates (the idea is that larger firms provide better career opportunities and thus have lower quit rates). Size is also used as another proxy for reputation. TW first determine the relationship between logs of sales and quit rates and size with a factor analysis. They find that sales have a positive coefficient and quit rates have a negative coefficient in determining size. Second they estimate the impact of size (as estimated through factor analysis) on long term and short term debt, and find that it has a positive impact on long term debt and a negative one on short term debt. J measures size with total assets and age (older firms are usually larger) and finds that the coefficient of size is positive for public long term debt and bank long term debt. HJ measure size with the logs of assets and find a negative relationship with bank debt (confirming one of the explanations given above that larger firms rely more on public debt).

Collateral value of assets: firms need funds to finance their fixed assets, on the other hand fixed assets may be used as a collateral for default debt. The main variable used to proxy the collateral value of assets is the ratio of fixed assets (inventory, plant and equipment) over total assets. TW also use the ratio of intangible assets over total assets as collateral value but find a non significant coefficient for both long and short term debt. $\mathrm{J}$ finds a positive coefficient for public debt and for bank debt, and a negative one for non bank private debt. $\mathrm{J}$ also measures the collateral value of assets by leverage and market to book ratio. Leverage has a positive impact on public debt and on bank debt, and a negative impact on private non bank debt. It must be said however that leverage is not a predetermined variable, as it contains the amount of debt itself, and it is thus correlated with the residuals. The market to book ratio is non significant for public debt, positive for private non bank debt and negative for bank debt.

Non debt tax shield: tax deductions for depreciation and investment tax credit are substitutes for the tax benefits of debt financing. TW use tax credit over total assets or depreciation over total assets but they find a non significant coefficient for both cases in explaining long and short term debt.

Growth: TW measure growth by R\&D as a percentage of sales or capital expenditure over total assets or with percentage variation of total assets; in all cases the coefficient for growth is positive for long term debt. By contrast, HJ measure growth by the market to book ratio and find a negative coefficient for growth (they also use R\&D/S and still find a negative coefficient). 
Volatility: this variable may have different impacts depending whether a demand or a supply function is estimated. On the one hand, firms with higher volatility of earnings would prefer to have the option to renegotiate the debt and thus prefer private debt to public debt, and would prefer a more secured long term debt than a short term one. On the other side lenders view more volatile firms as more credit risky because they may experience more states in which cash flows are too low to repay the debt and so they are less willing to lend to such firms. The net effect on the amount of bank loans thus is ambiguous. TW use the standard deviation of percentage changes in operating income but this variable is not significant for either long term or short term debt. $\mathbf{J}$ instead finds a negative coefficient for public debt (consistent with a demand function) and a non significant coefficient for private debt.

Uniqueness: the more unique the firm is the more specific are the workers skills and the capital characteristics. In the event of bankruptcy the more specialised the asset is the less its liquidation value and thus the lower the collateral value of fixed assets. These firms are considered more risky to lenders and thus they should find it more difficult to find loans. TW in fact find a negative coefficient of uniqueness for long and short term debts, measuring uniqueness by $\mathrm{R} \& \mathrm{D} / \mathrm{S}$, selling expenses, quit rates and a dummy variable which is the SIC classification. $J$ instead uses a dummy variable which is the product of fixed asset ratio by the SIC classification, and he finds a negative coefficient of this variable in explaining public debt, while he finds it not significant for private debt.

Profitability: the past profitability and thus the amount of earnings that could be retained to refinance future projects should also be an important determinant of capital structure. This variable should have opposite effects on demand and supply. For demand, profitability is an alternative source of financing and thus should be negatively related to debt; for supply, profitability should be a positive indicator of good financial health of the firm and should be positively related to credit allocation. Indicators are operating income over sales and operating income over total assets. TW use both measures and find a negative relationship for long term debt and short term debt.

The impact of environmental liability on capital structure has recently been analysed by Garber and Hammit (1909) (GH). In fact GH investigate whether CERCLA has increased the cost of capital of firms belonging to the chemical industry. Because Superfund liability adds an element of risk to the securities of a firm, investors will require higher returns as compensation of the increased risk. Superfund should thus increase the cost of capital. GH analyse whether firms' equity betas (the sensitivity of stocks' returns to fluctuations in returns on market portfolios) vary with the level of exposure to Superfund liability. For this they use six alternative exposure measures: 1) the number of NPL (National Priority List) sites at which a company is named, 2) the number of sites proposed for NPL at which a company is named, 3) measure 1 divided by real market equity, 4) measure 2 divided by real market equity, 5) the sum over sites in measure 1 of firm's shares of market equities of large PRPs at site, 6) sum over sites in measure 2 of firm's shares of market equities of large PRPs at site. Estimates from three sets of regressions are reported: in a first set all firms are 
included, but results about the impact of Superfund on return rates are ambiguous; in fact Superfund increases significantly the cost of capital only for the first two exposure measures used. In the other two sets of regressions GH divide the sample of firms between High market equity firms and Low market equity firms. For the first subsample Superfund increases significantly the cost of capital always, for all six exposure measures, while for the second subsample the coefficient relative to Superfund liability is not significant for any of the six exposure measures. It seems thus that investors of firms belonging to the first subsample are aware of Superfund liability and require higher returns for this, while investors of firms in the second subsample are not aware of Superfund liability.

An obvious difference with our paper is the dependent variable: GH want to explain the impact that CERCLA had on the cost of capital, and for this they analyse the rates of returns on securities. Conversely we want to explain the impact of CERCLA on the allocation of credit, and in fact our dependent variable is the proportion of bank lending. Moreover, GH do not want to explain the cost of capital in terms of firms' characteristics, the only explanatory variables are market rates of returns and Superfund exposure measure. We instead try to explain how bank loans depend on the characteristics of the industries. The last difference is the level of data aggregation and the sample considered: GH's sample comprises firms that belong to the chemical industry only, but they have monthly observations at firm level. We couldn't rely on this level of data but we had quarterly observations for 14 industries.

In a paper related to the previous one Barth and McNichols (1994) (BM) investigate the relationship between firms' share prices and estimates of Superfund liabilities. BM regress the firms' market value of equities over firms' assets, firms' liabilities and a proxy for environmental liability. With no disturbances or omissions the market value of equities should be equal to assets minus total liabilities, this is not the case in the analysis reported but still it is quite an accounting equality. Environmental liability is measured with alternative proxies: number of sites at which a firm is PRP, the sum of estimated clean up costs across all sites at which a firm is PRP (treating each PRP as $100 \%$ liable), partial allocation of remediation costs for each site at which a firm is PRP summed across all sites (PRP partially liable). All environmental proxies are significantly negative for cross-section time series analysis, while large percentages of them are significant for year by year cross section regressions. The liability measure with highest explanantory power (highest t-statistics and R-squared) is the number of sites at which a firm is nominated PRP.

The studies surveyed in this section have used firm-level data, but as discussed below we were able to use only industry-level data. So some of the variables described above, such as age, size, or uniqueness will be difficult to capture with industry-level data, while for some others, such as volatility, there may be significant aggregation problems.

\subsection{Description of Data and Variables}

We attempted to obtain US firm-level data on capital structure, but it is not possible to obtain published data on firms' bank borrowings. Such data has to be collected from the financial accounts of individual firms, and we did not have the resources to obtain such data. Nor we were able to gain access to the data sets of researchers who 
had collected such data. Thus we were forced to rely on industry-level data on bank borrowing; data on bank borrowing and other non-environmental variables was made available from Standard and Poor's. These consisted of quarterly observations from 1973 last quarter to 1997 second quarter at industrial level. The 14 industries, classified according to SIC code, for which data were available are Food and Tobacco, Textiles, Paper, Printing and Publishing, Chemicals, Petroleum and Coal, Rubber and Plastics, Stone Clay and Glass, Primary Metals, Fabricated Metals, NonElectrical Machinery, Electric and Electronic Equipment, Transportation Equipment, Instruments.

We next capture two different aspects of the impact of environmental liabilities on bank borrowing. The first aspect is a measure of the exposure of the different industries to clean-up costs under CERCLA. The only observation we had were clean-up costs directly related to CERCLA for 1996(2) for the following seven industries: Food and Tobacco, Chemicals, Petroleum and Coal, Primary Metals, Fabricated Metals, Non-Electrical Machinery, Electric and Electronic Equipment. This was available from Resources for the Future. This variable was scaled to the size of the industry by dividing it by the value of total industry assets in 1996 (2).

The second aspect we capture is the different liability regimes, as set out in the three phases noted at the start of this section. We captured this by the use of dummy variables. The first is a dummy variable (called CERCLA1) that takes the value zero from 1973 (4) to 1980 (4), the value one from 1981(1) to 1991(4), and the value zero thereafter. This variable is designed to capture the impact of the introduction only of CERCLA with environmental liability imposed only on firms. The second is a dummy variable (called CERCLA2) that takes the value zero from 1973(4) to 1991(4) and one thereafter, and is designed to capture the impact of Fleet Factors, making both firms and banks jointly liable.

These two sets of variables are then multiplied together. So for industries for which there is no data on clean-up costs, the environmental dummies are zero throughout; for industries for which we had data on clean-up costs, the dummy variables are either zero or positive, with the size of the positive variable reflecting the exposure of the industry to CERCLA liabilities.

We now describe the remaining non-environmental variables. The dependent variable is long term bank debt as a proportion of total liabilities. The (non-environmental) independent variables are:

- interest rate: long term real interest rates (three years maturity bonds); this would be expected to have a negative effect on demand for bank borrowing, a positive effect on supply, and so an ambiguous effect in a reduced-form equation; clearly it is also an endogenous variable;

- monetary base: this is expected to have a positive effect on the supply of bank lending and hence on the reduced-form;

- profitability: retained income over sales (net operating revenue). As discussed in 3.1, this represents an alternative source of funds to firms and so should reduce the demand for bank loans; on the other hand it is a measure of the financial health of 
the sector and so may make banks more willing to lend. So the overall effect in a reduced-form equation is ambiguous. Moreover, as the theoretical model makes clear, differences in environmental liability regime will affect firms' profits, so profitability may not be considered to be fully exogenous.

- equities: measured as stockholders equities over total assets. While this is not exactly the complement of bank debt, as in the capital structure of industries there is bank debt, non-bank debt and stockholders equities, it represents an alternative source of funds and so will reduce the demand for bank debt. However, it will be determined simultaneously with the level of bank debt.

- fixed assets ratio: measured as the value of property, plant and equipment as a proportion of total assets. This represents the collateral value of assets and as noted in 3.1 this should increase the supply of bank loans. It could also increase the demand for loans as to finance the capital investment. However, as noted above, the collateral value of assets diminishes the more highly specialised they are. It is difficult to capture this aspect with industry-level data.

- current assets ratio: measured by cash and securities divided by total current assets. This variable represents the liquidity and we would expect a negative impact on the demand for bank debt. However this is more correlated with short term debt than with long term debt.

- working capital ratio: measured as working capital divided by total assets; plays a similar role to current assets ratio.

- growth: this is designed to capture growth of investment opportunities. We used three different definitions: growth of total assets, growth of capital stock and depreciation over total assets; the results reported use the first definition; we obtained similar results with other definitions. Firms with high growth of investment opportunities will need more long-term debt in order to invest, so this will increase the demand for debt. Lenders could also consider firms (or industries) with high growth as firms (industries) with high future profitability potential and may be more willing to lend.

- volatility: measured by the standard deviation of profitability over 12 periods. As noted in 3.1, this variable is a proxy of credit riskiness and likelihood of financial distress: more volatile firms are more credit risky because they may experience more states in which cash flows are too low to repay the debt. The supply of bank debt is thus a decreasing function of volatility. On the demand side, more volatile firms would prefer to have the option to renegotiate the debt and thus prefer private to public debt. However there is an issue whether this variable is sensibly captured at industry level, since a lot of firm-specific volatility could be smoothed out by aggregation.

Before conducting the regressions, we carried out integration tests on all the variables and found that they are not integrated.

The relationships between the explanatory variables and demand and supply of bank loans are summarised in table 1. 


\section{$\underline{\text { 3.3 Regression results }}$}

Data are cross section-time series so fixed-factors panel regressions are estimated. Moreover, because the dependent variable lies between 0 and 1 a logit model is also estimated. This implies that coefficients do not really measure the direct effect of the explanatory variables on bank debt but rather on a transformed variable. The sign of the coefficient has the same meaning of a negative or positive impact of the explanatory variables on the dependent variables. While the coefficients of a non transformed regression would still be unbiased ${ }^{\natural}$, the transformation was necessary to test the significance of the coefficients. Because, as noted in 3.2, there may be problems of endogeneity of some variables, in particular interest rates, profitability and equities, instrumental variable estimation has been used; instruments are lagged values of these variables. This does not change the size and significance of the coefficients significantly. Finally, consistent GLS estimation was employed on the logit model.

We employed two variants of the model. The first included interest rates as a macroeconomic variable. However, as noted above, it may be considered inappropriate to include interest rates as an independent variable in a reduced-form regression (even if instrumented), and as an alternative we used a variant with the monetary base as a macroeconomic variable. For each variant we ran three models: Model I is a base case without any environmental liability variables; Model I introduces just the environmental variable CERCLA1; Model III introduces both environmental variables CERCLA1 and CERCLA2. Tables 2 and 3 present the results of the consistent GLS logit estimations with instrumental variables for Model I - III using the interest-rate and monetary-base variants respectively.

The underlying reduced-form model of bank borrowing is well-behaved: where we have been able to predict the sign of a variable, that variable has the correct sign (monetary base, equities, fixed asset ratio, current asset ratio, working capital ratio, growth); in all cases almost all variables are significant, at least at $10 \%$ and mostly at 5\%; and the coefficients are stable across the different models. The empirical results also strongly confirm the theory about the impact of environmental liability on bank borrowing. The introduction of liability only on the firm has a strong positive effect on bank borrowing. When joint liability on firms and banks was introduced following Fleet Factors bank borrowing fell; in the interest rate model the coefficient on CERCLA2 remains positive and significant, though smaller than on CERCLA2, while in the monetary base model, the coefficient on CERCLA2 is positive but insignificant, suggesting that borrowing fell back close to its pre-CERCLA level.

\subsection{The Impact of CERCLA on US Bank Borrowing}

\footnotetext{
${ }^{7}$ It is possible then to use the coefficient of the untransformed regression to tell us something more about the impact of the independent variables on the dependent one. For this reason, simple OLS panels were also performed. The OLS results are not reported here.

${ }^{8}$ These are performed by first estimating the variance-covariance matrix using OLS and then estimating the coefficients using GLS; the process is then iterated to get better results.
} 
While the regressions confirm the theory set out in section 2, as presented they give no indication of the scale of the impact of environmental liability on bank borrowing in different industries. To assess this we have the used the model with monetary base to predict the effect of the different liability regimes on bank borrowing in different industries, ceteris paribus. What we have done is to set all the independent financial variables for each industry at their mean values; denote the vector of the variables for

industry $i$ by $\bar{X}_{i}$. We have then used the estimated coefficients (denoted $\hat{\beta}$ of the monetary-base variant of Model III to calculate the following three estimates of expected bank borrowing in industry $i$ with (i) no liability; (ii) liability only on firms; (iii) joint liability on firms and banks:

$$
\begin{aligned}
& y_{i}^{1}=\hat{\beta}_{0 i}+\hat{\beta}_{1} \bar{X}_{i} \\
& y_{i}^{2}=\hat{\beta}_{0 i}+\hat{\beta}_{1} \bar{X}_{i}+\hat{\beta}_{2} \text { CERCLA1 } \\
& y_{i}
\end{aligned}
$$

and

$$
z_{i}=\frac{\exp \left(y_{i}\right)}{1+\exp \left(y_{i}\right)}
$$

where $y$ is the estimated logit transformation of the proportion of bank debt and $z$ is the proportion of bank debt.

Note that it is only the constant-term which has an industry-specific estimated coefficient. The resulting three estimates of expected bank lending for the seven industries which have non-zero environmental liability variables are shown in columns (1) to (3) of Table 4. Columns (4) and (5) then show the percentage difference in expected bank borrowing from the no liability base case that would result from imposing environmental liability only on firms, and jointly on firms and banks respectively. What this shows is that in industries such as chemicals and primary metals which have high CERCLA liabilities, the introduction of liability on firms caused a significant increase in bank borrowing (above 15\%) as firms tried to protect equity-holders from these liabilities. However, if liability is imposed jointly on firms and banks, then the impact on bank borrowing relative to no liability is trivial.

\section{Conclusions}

In this paper we have analysed the consequences for the capital structure of firms, and particularly their use of bank borrowing, of imposing legal environmental liability either on firms alone or jointly on firms and banks. We used a simple theoretical model to show that the imposition of liability only on firms would lead to an inefficiently high use of bank borrowing, as well as an inefficiently low level of effort to reduce environmental damage, while imposing liability jointly on firms and banks had a more ambiguous effect on bank borrowing, but under plausible assumptions would lead to lower bank borrowings than when liability is imposed only on firms, and could lead to higher or lower bank borrowings than with no liability at all. We then used US industry-level data to estimate a reduced-form model of bank borrowing 
which confirmed the theoretical findings and showed that for industries heavily exposed to environmental liabilities the imposition of liabilities on firms only had caused bank borrowing to rise by $15-20 \%$, but then when liability was extended to banks, borrowings fell back almost to the level expected without any environmental liabilities.

The research was constrained by the difficulty of getting access to firm-level data, and it would be interesting to check if the results are upheld using such data. Further work could also be done on the dynamic aspects of the econometric model using industrylevel data. Nevertheless, we believe that our work provides a useful empirical analysis of the impact of environmental liabilities on financial structures of firms. Moreover our findings suggest that the extension of environmental liability from firms to banks, which would be desirable on the grounds of improving the incentives for firms to take adequate steps to reduce environmental damage, may not have the drastic consequences for bank lending to firms that some commentators had feared. 
Table 1: Relationship between bank ddebt abd financial variables

\begin{tabular}{|l|c|c|c|}
\hline \multicolumn{1}{|c|}{ Variable } & Demand & Supply & Net effect \\
\hline Interest Rate & - & + & \\
\hline Monetary Base & & + & + \\
\hline Profitability & - & + & - \\
\hline Equities & - & & + \\
\hline Fixed Asset Ratio & + & + & - \\
\hline Current Asset Ratio & - & & - \\
\hline Working Capital & - & & + \\
\hline Growth & + & + & + \\
\hline Volatility & + & - & \\
\hline CERCLA1 & + & & \\
\hline CERCLA2 & & & \\
\hline
\end{tabular}


Table 2: Estimates of Models I - III Using Interest Rate

\begin{tabular}{|c|c|c|c|}
\hline Variable & Model I & Model II & Model II \\
\hline Interest Rate & $-0.008 *$ & $-0.016 *$ & $-0.016 *$ \\
\hline Profitability & $0.546^{*}$ & $0.726 *$ & 0.716* \\
\hline Equities & $-2.059 *$ & $-1.967 *$ & $-1.838 *$ \\
\hline Fixed Asset Ratio & 2.915* & $2.831 *$ & 2.863* \\
\hline Current Asset Ratio & -0.070 & -0.056 & -0.062 \\
\hline Working Capital & $-1.957 *$ & $-1.816^{*}$ & $-1.823^{*}$ \\
\hline Growth & 0.144 & $0.169^{\circ}$ & $0.174^{\circ}$ \\
\hline Volatility & -0.172 & $-0.168^{\circ}$ & $-0.172^{\circ}$ \\
\hline CERCLA1 & - & 4.139* & $5.362 *$ \\
\hline CERCLA2 & - & - & 2.130* \\
\hline Adjusted $R^{2}$ & 0.824 & 0.834 & 0.835 \\
\hline
\end{tabular}

Table 3: Estimates of Models I - III Using Monetary Base

\begin{tabular}{|c|c|c|c|}
\hline Variable & Model I & Model II & Model II \\
\hline Monetary Base & $1.016 *$ & $1.443 *$ & $1.414^{*}$ \\
\hline Profitability & 0.353 & $0.476^{\circ}$ & $0.479^{\circ}$ \\
\hline Equities & $-1.700 *$ & $-1.513 *$ & $-1.499 *$ \\
\hline Fixed Asset Ratio & $3.154 *$ & 3.010* & $3.005 *$ \\
\hline Current Asset Ratio & $-0.125 *$ & $-0.120 *$ & $-0.120 *$ \\
\hline Working Capital & $-1.651 *$ & $-1.307 *$ & $-1.311 *$ \\
\hline Growth & $0.165^{\circ}$ & 0.195* & $0.196 *$ \\
\hline Volatility & $-0.276 *$ & $-0.303 *$ & $-0.300 *$ \\
\hline CERCLA1 & - & $4.673 *$ & $5.043 *$ \\
\hline CERCLA2 & - & - & 0.701 \\
\hline Adjusted $R^{2}$ & 0.829 & 0.841 & 0.841 \\
\hline
\end{tabular}

* Significant at $5 \%$

- Significant at $10 \%$ 
Table 4 Impact of CERCLA on Bank Borrowing

\begin{tabular}{|l|c|c|c|c|c|}
\hline & $(1)$ & $(2)$ & $(3)$ & $(4)$ & $(5)$ \\
\hline \multicolumn{1}{|c|}{ Industry } & Model I & Model II & Model III & $\begin{array}{c}(2) /(1) \\
\%\end{array}$ & $\begin{array}{c}(3) /(1) \\
\%\end{array}$ \\
\hline Food and Tobacco & 10.577 & 11.061 & 10.619 & 4.6 & 0.8 \\
\hline Chemicals & $\mathbf{6 . 7 7 6}$ & $\mathbf{7 . 9 6 5}$ & $\mathbf{6 . 8 7 3}$ & 17.5 & 1.4 \\
\hline Petroleum \& Coal & $\mathbf{5 . 3 8 7}$ & $\mathbf{5 . 6 3 8}$ & $\mathbf{5 . 4 0 9}$ & 4.7 & $\mathbf{0 . 4}$ \\
\hline Primary Metals & $\mathbf{8 . 1 0 3}$ & $\mathbf{9 . 3 6 7}$ & $\mathbf{8 . 2 0 7}$ & 15.6 & 1.3 \\
\hline Fabricated Metals & $\mathbf{1 4 . 8 6 5}$ & $\mathbf{1 6 . 1 3 9}$ & $\mathbf{1 4 . 9 7 3}$ & $\mathbf{8 . 6}$ & $\mathbf{0 . 7}$ \\
\hline Non-Elec. Equip. & $\mathbf{1 0 . 2 0 6}$ & $\mathbf{1 0 . 2 1 1}$ & $\mathbf{1 0 . 2 0 7}$ & $\mathbf{0 . 5}$ & $\mathbf{0 . 0}$ \\
\hline Electr. Equip. & $\mathbf{6 . 2 2 4}$ & $\mathbf{6 . 3 0 5}$ & $\mathbf{6 . 2 3 1}$ & 1.3 & $\mathbf{0 . 1}$ \\
\hline
\end{tabular}




\section{REFERENCES}

Balkenborg, D. (1997) "Bargaining Power, Judgement-Proofness and the Impact of Vicarious Liability", University of Southampton Discussion Paper in Economics and Econometrics 9709.

Baltagi, B. (1995) Econometric Analysis of Panel Data, J. Wiley and Sons.

Barbera A. J., McConnell V., (1990): “The Impact of Environmental Regulations on Industry Productivity: Direct and Indirect Effects", in Journal of Environmnental Economics and Management, 18, 50-65.

Barth M. E., McNichols M. F., (1994): "Estimation and Market Valuation of Environmental Liabilities Relating to Superfund Sites", in Journal of Accounting Research, 32, 177-209.

Boyer, M. and J-J Laffont (1997) "Environmental Risks and Bank Liability" Europeqn Economic Review, 41(8) 1427 - 1460

Feess, E. and U. Hege (1997) "Lender Liability, Capital Structure and Mandatory Coverage", mimeo, University of Frankfurt.

Garber S. and J.K Hammitt (1998) "Risk premiums for Environmental Liability: Does Superfund Increase the Cost of Capital?" Journal of Environmental Economics and Management, 36 (3), 267 - 294

Gollop F. M., Roberts M. J., (1983): "Environmental Regulations and Productivity Growth: The Case of Fossil-fuelled Electric Power Generation", in Journal of Political Economy, 91(4), 654-74.

Heyes, A. (1996) "Lender Penalty for Environmental Damage and Equilibrium Cost of Capital", Economica, 63, 311 -323

Houston, J. and C. James (1996) "Bank Information Monopolies and the Mix of Private and Public Debt", The Journal of Finance, 51, 1863-1889

Jaffe A. B., Palmer K., (1997): "Environmental Regulation and Innovation", The Review of Economics and Statistics, 79(4), 610-19.

Jewell, T (1997a) "Contaminated Land" in A. Waite and T. Jewell (eds.) Environmental Law in Property Transactions, Butterworths, London, 161 191.

Jewell, T. (1997b) "Causing or Knowingly Permitting" in A. Waite and T. Jewell (eds.) Environmental Law in Property Transactions, Butterworths, London, $238-247$. 
Johnson, A. (1997) "An Empirical Analysis of the Determinants of Corporate Debt Ownership Structure”, Journal of Financial and Quantitative Analysis, 32 (1), $47-69$.

Lewis, T. and D. Sappington (1997) "Using Decoupling and Deep Pockets to Resolve Judgement-Proofness Problems", American Economic Review (forthcoming).

McKenzie, G. and S. Wolfe (1998) "Environmental Risk Management by UK Financial Institutions" mimeo, Department of Management, University of Southampton.

Pitchford, R. (1995) "How Liable Should a Lender Be? The Case of Judgement-Proof Firms and Environmental Risk", American Economic Review, 85, 1171 1185

Segerson, K. (1993) "Liability Transfers: An Economic Analysis of Buyer and Lender Liability", Journal of Environmental Economics and Management, 25, 46 63.

Titman, S and R. Wessels (1988) "The Determinants of Capital Structure Choice" The Journal of Finance, 43(3), 689 - 702.

Valentini, L (1999) "Credit Rationing and Capital Structure: a Survey of Empirical Studies", Discussion Paper in Economics and Econometrics 9905, University of Southampton. 